https://doi.org/10.46291/ISPECIJSSHvol4iss5pp511-534

\title{
Socio-Cultural Psychology in Reading Behavior of Employees and Determining Organization
} Culture

\author{
Mahalakshmi. ${ }^{1}$, Shobha.T ${ }^{2}$, Banashri $^{3}$ \\ ${ }^{1}$ Prof. Seshadripuram College, Head of the Department of Commerce \& Management, Bangalore, India. \\ maha.5299@gmail.com \\ ${ }^{2}$ Prof. Seshadripuram First Grade College, Department of Mathematics, Bangalore, India. \\ shobhabt@yahoo.com \\ ${ }^{3}$ Assoc. Prof. Seshadripuram First Grade College, Department of Commerce \& Management, Bangalore, \\ India.nethratr@gmail.com
}

\begin{abstract}
In the present diverse Organization culture, every Management need to determine motivational factors, policies, events and provide culture-based targets to lead the organization to achieve goals. In this journey every organization should understand the behavioral factors of their workforce. Psychology, on the other hand is a study of mind and behavior of human beings. This study considers important elements of psychology to study behavior of human at a said time to identify factors which motivates employees at workplace and improve efficiency. Understanding employee's behavior also poses useful to set acceptable policies and work culture to the employees. This study also includes how behavior and thinking vary across situations and cultures, how it affects human behavior and thinking. A Likert scale is constructed based on important elements of psychology, the scores are analyzed to examine which point gets high score, further descriptive statistics was calculated to examine its variability and Reliability test on the construct was conducted to check whether the construct is reliable to the study are not.
\end{abstract}

Key words: Organization Culture, Behavioral Factors, Psychological Factors, Workplace Culture.

\section{INTRODUCTION}

Psychology is a systematic, disciplined form of knowledge, when the question of psychology arises in relation to human behavior it has to approach its subject matter, in this complexity it is not an easy task to draw demarcation line among behavior of people belonging to one kind of behavior. Every human is tending to change with the matter of time and changes in environment and surroundings. If psychology proves a behavioral result today, tomorrow same set of people may show change in their behavior in another result. From research it is proved that culture and behavior of people remains constant only when connected to social- culture and customs. Socio-cultural on the other hand is one of the modern theories in psychology which studies about the contribution of society to individual growth and development by examining the

Year 4/ 2020, Volume-4, Issue-5 | www.ispecjournal.org 
rules of social groups and subgroups. Socio cultural psychology is about influence of cultural and social environment on behavior of humans who follow customs beliefs and language and to examine whether that behavior is appropriate or inappropriate. Important principles of Socio-cultural Psychology include Humans are social beings thus should develop belongingness, their culture influence their behavior, all humans have social -self and people views of the world are resistant to change and development by the community and culture. People employed in one organization or the other, working as employees throughout the world constitute 59.7 percent as per (Bureau of Labor Statistics, 2016). An average person spends 90,000 hours at the workplace over lifetime, (Writer Annie Dillard). Thus, a major portion of one's life time is spent in workplace, the organizations decide to adopt many practices based on socio-cultural behavior of humans to keep them updated with outside world. There is a need for a common ground to understand what common culture can prove to be successful for any work environment. This study establishes a multidisciplinary study between Socio-cultural Psychology and Organization culture based on human behavior which is one of the important aspects of Human resource management.

Organization culture is the way every employee behaves in an environment of shared beliefs and values established by leaders which are reinforced through various methods, ultimately shaping employee's behavior and understandings in an organization. Organization culture are based on founders' values and preferences, demands and goals. It is maintained through proper selection of culture, leadership styles, human resource strategies, reward systems, activities based on preferences of employees etc. These elements of culture changes from organization to organization.

The 9 elements of psychological behavior include social cognition, Attitudes, prejudice and Interpersonal relationships of employee behavior in the workplace, expectations, motivation, social and cultural behavior and discriminations. This study focuses on three major areas of occupation they are Educational Institutions, IT Industries and Small and Medium enterprises and others are grouped separately. The main focus of sociocultural psychology is to analyze and describe human behavior which occurs in a given situation between the mental state and social factors. Thus, the goal of sociocultural psychology is to examine various factors which make an individual behave in a certain way, this approach is to explain how a specific set of workforces in an organization behave and how to interpret the information of their behavior, thoughts and feelings.

Organizational culture is different and unique in each individual organization. The values and behavior contribute to the unique social and psychological environment within the organization. For an organization to explore and extract efficient work it needs to study its employees' behavioral pattern and plan policies and procedures. Psychology explores mental process and behavior including perception, emotion,

Year 4/ 2020, Volume-4, Issue-5 | WwW.ispecjournal.org 
intelligence, cognition, subjective experiences, motivation, brain functioning and personality. This leads to interaction between interpersonal relations, family and psychological resilience. The very characteristics of psychology is to study behavior and provide solution to problems, increase job satisfaction, and improve workplace dynamics.

Workplace culture mainly constitutes layout of the place, access to certain things which are custom based or culture-based encouragements, celebrations, events, setting targets based on seasonal and cultural backgrounds etc. However, this study focuses on motivation and productivity in workplace by adopting suitable organizational culture. The tactics like contests, sales quotas, personal appraisal, commission improves motivation. A construct based on these elements is developed to determine and design policies and practices to improve productivity, a questionnaire with statements on Likert scale is constructed. In the process of this study an attempt is made to determine the factors for developing work culture and how thinking and behavior vary across situations in day to day working of the organization. An empirical study choosing limited respondents from various workplaces to understand their behavior and thinking in given normal situation is conducted in the study. The respondents from the field of employees working in education sector, IT, Small and medium industries with an open-end category are considered to conduct a survey through a questionnaire based on Likert scale. This construct is tested for reliability using internal consistency test under Cronbach Alpha test.

\section{LITERATURE REVIEW}

This part of the content includes discussion of aspects of Sociocultural psychology and description and findings of other authors in their study regarding behavior of employees for the elements selected for the study. Firstly, authors who have listed elements of psychology to identify human behavior is discussed and secondly, discussions related to elements included in the study is reviewed, authors who have discussed these elements and their findings are considered.

A soviet psychologist Lev Semyonovich Vygotsky (1896-1934), proposed that what children learn and perceive change from culture to culture and specific to each individual society. While cognitive process may mostly remain same while passing from generation to generation. Social psychology topics includes the social cognition, attribution theory, social influence, prejudice and discrimination, interpersonal processes, aggression, attitudes etc. (Saul McLeod, 2007).

Behavioral factors which are actually useful for performance management of employees are evaluation and reward system, structural, behavioral, cultural influencing the performance of workforce, these are not taken into effect enough to determine performance management system (André A. de Waal, 2006).

Year 4/ 2020, Volume-4, Issue-5 | WwW.ispecjournal.org 
There are appropriate employer and employee behavior, the expected behavior of employee from employer and from employer on employee contributes to the entire company culture or work culture and also integral to the success of the organization culture (Laura Berlinsky-Schine).

Socio cultural theory is an emerging theory in Psychology, it stresses the interaction between developing people and the culture in which they live (Kendra Cherry, 2019).

Understanding business psychology leads to improved solutions. Many business organization se the tool of psychology to understand an individual's behavior within a group, and social psychology may be the tool that can lead to even more efficient, adaptive, and innovative practices (Corinne McGinley).

Employee behavior is an employee's reaction to a particular situation at workplace. They need to behave sensibly and gain appreciation and respect from others. Employees need to maintain healthy work culture and follow all rules and regulations at workplace behave sensibly at workplace not only to gain appreciation and respect from others but also to maintain a healthy work culture.

\section{Objectives and Methodology}

The present globalization culture in organizations have brought all culture and religion together irrespective of color or creed. Workforce who come together to work for common goal should also coordinate with each other with the culture and practices or organization in workplace. Organization culture has to be set by the employer, the employer should determine workplace culture based on external and internal environment and mainly based on requirements of employees. To understand what kind of common requirement employees, have in a certain workplace is attempted to understand through this study.

The objective of the study is as follows

1. To determine factors for developing organization work culture

2. To examine whether there is change in behavior of employees in a given work culture

\section{Methodology: \\ Primary data:}

Data collection was concentrated only in Bangalore city, Karnataka state, India. The residential location of the researchers of the authors was considered for the study.

Survey: Important elements of psychology considered for understanding workplace behavior of employee's social cognition, Attitudes, prejudice and Interpersonal relationships of employee behavior in the work place, expectations, motivation, social and cultural and discrimination based on which an employee

Year 4/ 2020, Volume-4, Issue-5 | www.ispecjournal.org 
perform. Even though there are many issues related to each element only behavior constraint to their occupation and commonly observed questions are framed in questionnaire in the format of Likert scale to obtain responses. Three sectors of occupation, employees working in Educational institutions, Information technology Industry, Small and Medium scale Industry are considered as our respondents.

Descriptive statistics: Likert type data, needs descriptive statistics with median, mode for central tendency, frequencies or standard deviation for variability, skewness kurtosis range is also observed. An analysis is drafted for the same with inference.

The points of interest is covered in the likert scale a reliability test on the construct is conducted using internal consistency test for which Cronbach Alpha test is carried out to test the reliability of the construct. If the Alpha values are >and equal to 0.9 the internal consistency is considered as excellent.

Secondary data: Articles from various journals National and International, books on psychology, and books based on sociology, print and e format materials are referred to draw literature and conduct the study.

\section{Limitations of the study}

There is no authentic information on population of the study a random sampling method is used and nearly 900 respondents were contracted through mails but, only 43 responses have been received till date.

1. One of the major limitations faced is responses from employees were very poor. Time period considered for the study is also limited.

2.The authors were able to reach to the respondents within the city of their residence and within their contact within this short period of time after conceptualizing the topic for research.

3. Authors themselves had the fear from their own employer for the type of questions and statements drafted in the questionnaire to be answered among the employees in the organization they work.

4. Constraint of time period of the study

5. Population selected were not interested in filling the google form

6. Personally contacting the population for filling the questionnaire was not possible due to the present COVID pandemic crisis.

\section{DATA ANALYSIS}

The moral responsibility of all employees is to abide by the organizations policies. To give attendance, whatever maybe one's problem, to follow the timing of organization with no foolish excuse of traffic and transportation, timings are same to every person in the organization irrespective of level and hierarchy. Female counterparts need to be treated with respect and who ever ill-treats female employees uses abusive

Year 4/ 2020, Volume-4, Issue-5 | www.ispecjournal.org 


\section{ISSN 2717-7262 ISPEC Journal of Social Sciences \& Humanities}

and obscene remarks are not at all acceptable at workplace. It is a crime to damage or misuse properties of the organization; every employee is capable of buying a pen or any stationery instead of carrying away things belonging to office. Speaking loudly over phone is not acceptable at workplace, talking with high voice whether it is from employer to employee or vice versa is not acceptable. Internal strategies and plans of the organization must not be disclosed to outsiders and it is unethical to break your higher authority's trust. Information tampering is a crime, recording one's conversation without the other persons permission is a crime. Everyone needs to respect the organization to expect the same in return. Thus, setting a right organization culture becomes a necessity to every organization to give standard behavior model to all employees which not only maintains harmony but also motivates the employees at their work. To develop this model factors influencing the human behavior have to be determined. Human factors differ from each individual and it becomes difficult to set different organization culture to each one's behavior. Every organization can adopt an organization culture of its own on set standards of behavior. The survey conducted helps in determining few factors which provide for developing a common organization culture. Further this survey also provides to the question whether the behavior of employees change in a given work culture.

Firstly, the survey data is classified based on its score to examine which point scores how much on each point and examine which sector employees agree and strongly agree to which point on Likert scale highly. Only 43 respondents submitted the google form(limitations)

Table1. Table showing number of respondents for each sector

\begin{tabular}{|l|l|}
\hline Sectors & No. of Respondents \\
\hline Educational Institutions & 28 \\
\hline IT Industries & 05 \\
\hline SMEs & 02 \\
\hline Others & 08 \\
\hline Total & 43 \\
\hline
\end{tabular}

Year 4/ 2020, Volume-4, Issue-5 | WWW.ispecjournal.org 


\section{ISSN 2717-7262 ISPEC Journal of Social Sciences \& Humanities}

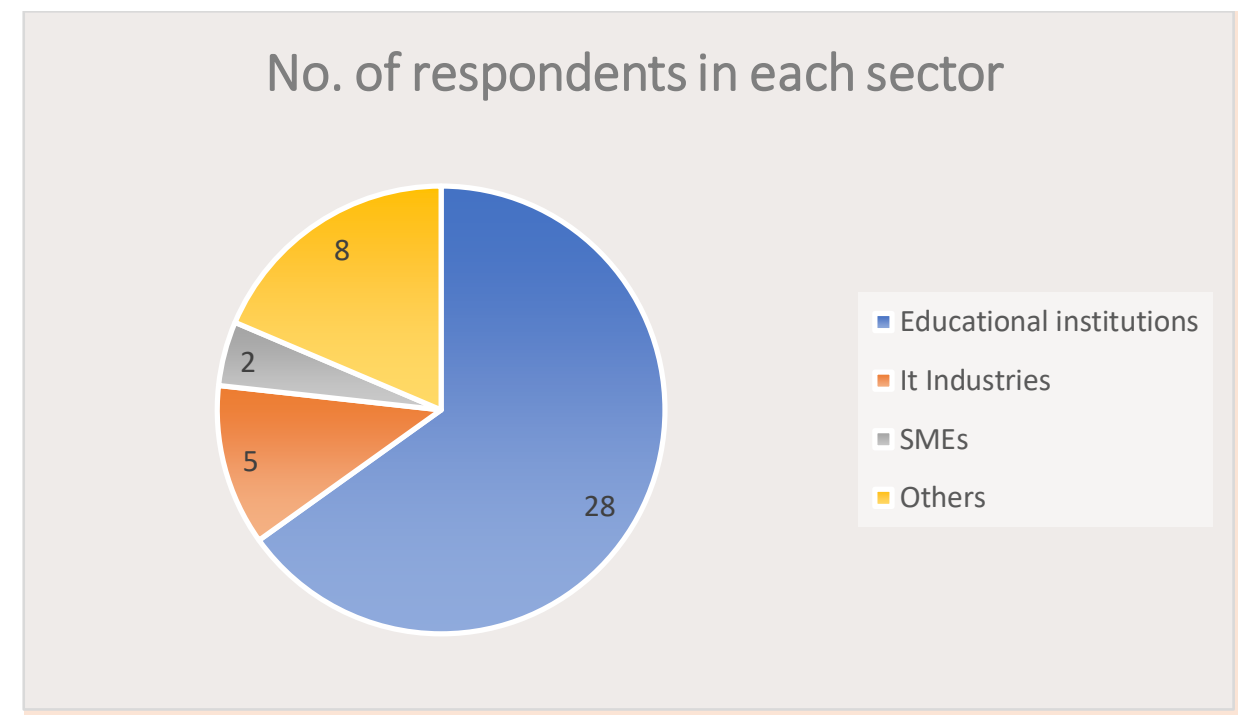

Figure 1

Number of respondents from educational institutions are 28 and respondents from IT industry are 5 and from SMEs are 2 and other sectors 8 responses.

\section{Analysis of survey data}

The questionnaire survey data was tabulated and frequency of 5 points on scale 1 and 2 and their scores among each sector is drafted on separate statements (Appendix I)

The inferences are as follows:

Responses from employees of Educational institutions: -

Scale 1: All 10 questions have highest number of respondents with agree and strongly agree answers, for statement No.1, 2,3, 4, 6,7,8 which are conscious behavior with boss, recognition to ones work in team, motivation due to informal organization structure and highest no. of employees strongly agree for performance-based promotion for high productivity in an organization.

Scale 2: Highest number of respondents agree that their salary is in constraint with their expectations, and highest number of employees agree that socializing increases belongingness towards the organization, and highest number of employees agree that there should be common work culture in all organizations. Responses from IT industry employees: -

Scale 1: Highest number of respondents agree with statement No. 1,2,4, 6,7 which after conscious behavior with boss, recognition to their work, Informal gathering, and organization structure motivates develops belongingness.

Year 4/ 2020, Volume-4, Issue-5 | WWW.ispecjournal.org 
Scale 2: Highest number of employees either disagree or neutral about salary, match with remuneration and work, gender discrimination is demotivating highest number employees. There is neutral response for performance-based promotion is increasing productivity

Responses from SMEs employees: -

Scale 1: All employees agree on all points of this scale

Scale 2: employees agree or strongly agree on all points

Responses from employees working in other sectors:-

Scale 1: The responses are highest with socializing, performance-based promotion to increase productivity, recognition of ones works among peers

Scale 2: There are highest number of respondents who agree with socializing, common culture and more socializing events

Conclusion: From the above inference it indicates that There is high score for recognition, informal organization structure for Motivation, Performance based promotion from scale 1. The responses from scale 2 , commonly agreed with high score is socializing and common work culture.

\section{Descriptive statistics}

The scores of the likert scale (Appendix 1), for each scale $1 \& 2$ is drafted separately. The descriptive statistics for likert scale mainly should measure Median and mode and frequency. Appendix I

From the data set in Table ,2,3,4 \&5 in (Appendix 1) the descriptive statistics of each sector based on survey scale 1 and 2 is as follows:

\section{Educational Institutions Scale $1 \& 2$}

The construct on likert scale includes variables of interest of the study like Social cognition, Attitudes, prejudice and Interpersonal relationships of employee behavior in the work place, expectations, motivation, social and cultural and discrimination based on which an employee perform (Appendix II). The inference of descriptive statistics of the likert scale is as follows:

Scale 1 which states about social cognition, attitude, prejudice and interpersonal relationships tend to show high mean ranging from 2.3 to 10.3 , median ranging 2.5 to 10.5 and mode 2 to 12 which specifically high with strongly agree point and standard deviation ranges from .8 to 3.6 again with strongly agree point to mean that scores are near to mean, and minimum score is low and maximum score is high indicating that all statements in scale has high level of agree points than other points.

Year 4/ 2020, Volume-4, lssue-5 | www.ispecjournal.org 
Scale 2 which states about expectation, motivation, social and cultural and gender discrimination shows the response with mean ranging from and very high standard deviation indicating spread of scores over a wide range. Median has high value and mode also with high level indicating that respondents are more inclined towards accepting or agreeing to all points in scale 2 .

\section{Information technology industries}

Scale 1 The mean value is ranging from 0 to 1.3 and median is 0 to 1 and mode is 0 to 1 and standard deviation is low with very near to mean value showing high correlation with agree point for all statements Scale 2 responses also shows similar calculations with mean below 1 and standard deviation below one and median as 2 showing high level for agreeing point.

\section{SMEs}

Scale 1 the standard deviation is below 1 indicating near to mean range indicating more supportive to the statements

Scale 2 also indicates SD with in the range of mean to show more agreeing points for all statements

\section{Others}

Scale 1 Mean value ranges from 0 to 1 and standard deviation less than 1 positive values indicating close relationship with mean value and median with 1 and mode with 1 indicating more accepting range of statements. And similar with scale 2.

Conclusion: High standard deviation from mean indicates high variability between opinions of the employees of Educational institutions. The difference between mean and SD for IT sector is not so very high, this indicates the opinion are not more variable from the construct. The difference between mean and $\mathrm{SD}$ is moderate thus there is no much variablility. In case of other sectors the varianbility is low.

For example one table of descriptive statistics on responses of employees of educational Institutions is added.

Year 4/ 2020, Volume-4, Issue-5 | WwW.ispecjournal.org 


\section{ISSN 2717-7262 ISPEC Journal of Social Sciences \& Humanities}

Table 2: Table showing descriptive statistics of responses from employees of educational institutions for scale 1 and 2( AppendixII)

\begin{tabular}{|c|c|c|c|c|c|c|c|c|c|}
\hline \multicolumn{2}{|c|}{ Strongly disagree } & \multirow{2}{*}{$\begin{array}{l}\text { Disagree } \\
\text { Mean }\end{array}$} & \multirow[b]{2}{*}{2.9} & \multicolumn{2}{|c|}{$\begin{array}{l}\text { Neither agree nor } \\
\text { disagree }\end{array}$} & \multirow{2}{*}{$\begin{array}{l}\begin{array}{l}\text { Strongly } \\
\text { agree }\end{array} \\
\text { Mean }\end{array}$} & \multirow[b]{2}{*}{8.5} & \multirow{2}{*}{$\begin{array}{l}\text { Agree } \\
\text { Mean }\end{array}$} & \multirow[b]{2}{*}{10.3} \\
\hline Mean & 2.7 & & & Mean & 3.6 & & & & \\
\hline $\begin{array}{l}\text { Standard } \\
\text { Error }\end{array}$ & 0.260342 & $\begin{array}{l}\text { Standard } \\
\text { Error }\end{array}$ & 0.481894 & $\begin{array}{l}\text { Standard } \\
\text { Error }\end{array}$ & 0.635959 & $\begin{array}{l}\text { Standard } \\
\text { Error }\end{array}$ & 1.166667 & $\begin{array}{l}\text { Standard } \\
\text { Error }\end{array}$ & 0.597216 \\
\hline Median & 2.5 & Median & 2.5 & Median & 4 & Median & 8 & Median & 10.5 \\
\hline Mode & 2 & Mode & 2 & Mode & 4 & Mode & 12 & Mode & 10 \\
\hline $\begin{array}{l}\text { Standard } \\
\text { Deviation }\end{array}$ & 0.823273 & $\begin{array}{l}\text { Standard } \\
\text { Deviation }\end{array}$ & 1.523884 & $\begin{array}{l}\text { Standard } \\
\text { Deviation }\end{array}$ & 2.01108 & $\begin{array}{l}\text { Standard } \\
\text { Deviation }\end{array}$ & 3.689324 & $\begin{array}{l}\text { Standard } \\
\text { Deviation }\end{array}$ & 1.888562 \\
\hline $\begin{array}{l}\text { Sample } \\
\text { Variance }\end{array}$ & 0.677778 & $\begin{array}{l}\text { Sample } \\
\text { Variance }\end{array}$ & 2.322222 & $\begin{array}{l}\text { Sample } \\
\text { Variance }\end{array}$ & 4.044444 & $\begin{array}{l}\text { Sample } \\
\text { Variance }\end{array}$ & 13.61111 & $\begin{array}{l}\text { Sample } \\
\text { Variance }\end{array}$ & 3.566667 \\
\hline Kurtosis & -1.0435 & Kurtosis & 0.819153 & Kurtosis & 0.305476 & Kurtosis & -0.30951 & Kurtosis & -0.56861 \\
\hline Skewness & 0.686982 & Skewness & 1.149166 & Skewness & -0.02869 & Skewness & 0.265521 & Skewness & -0.41568 \\
\hline Range & 2 & Range & 5 & Range & 7 & Range & 12 & Range & 6 \\
\hline Minimum & 2 & Minimum & 1 & Minimum & 0 & Minimum & 3 & Minimum & 7 \\
\hline Maximum & 4 & Maximum & 6 & Maximum & 7 & Maximum & 15 & Maximum & 13 \\
\hline Sum & 27 & Sum & 29 & Sum & 36 & Sum & 85 & Sum & 103 \\
\hline Count & 10 & Count & 10 & Count & 10 & Count & 10 & Count & 10 \\
\hline
\end{tabular}

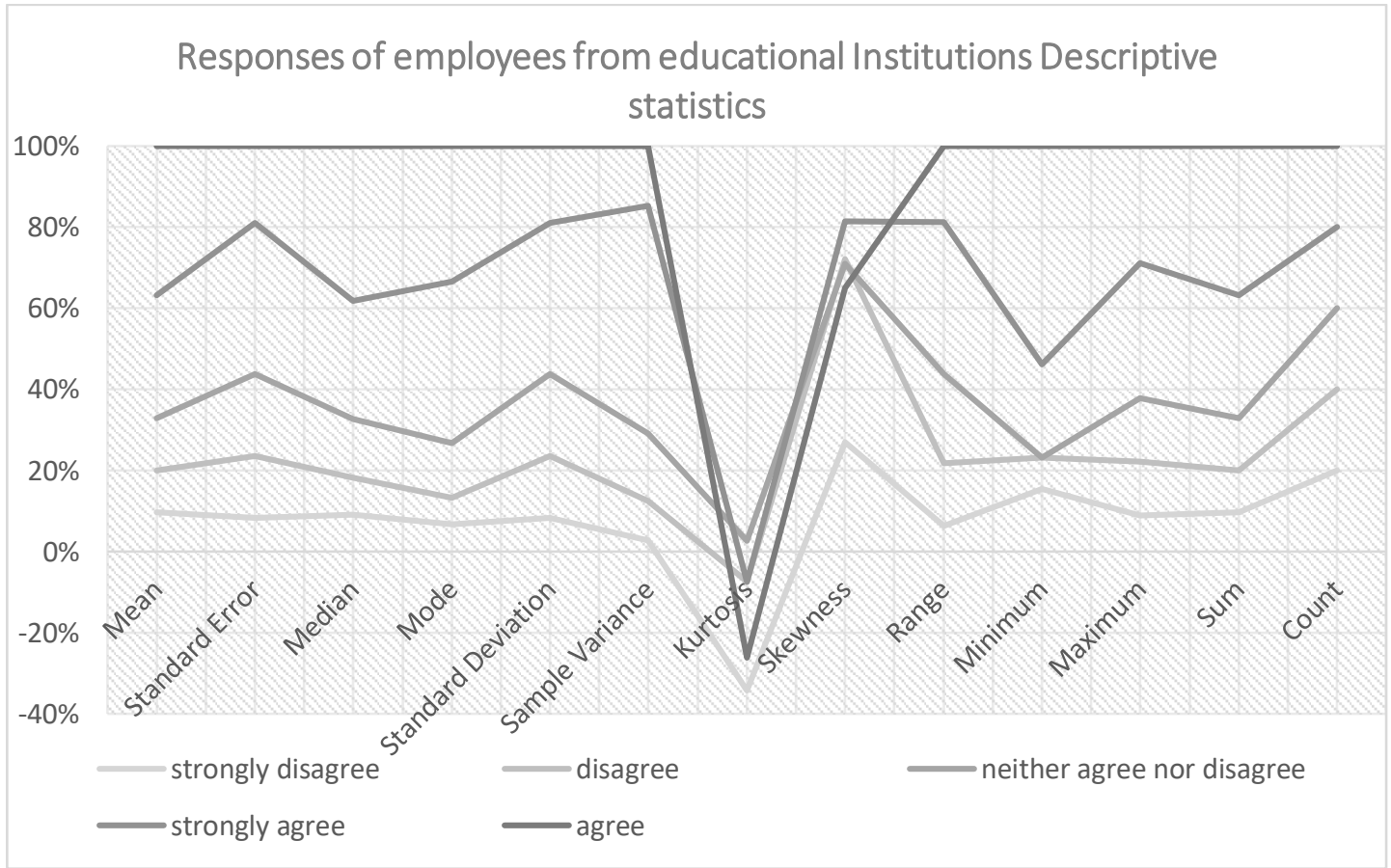

Figure 2

The level of agreeing to the points is high than their disagreement

Year 4/ 2020, Volume-4, Issue-5 | WwW.ispecjournal.org 
Scale 2

\begin{tabular}{|c|c|c|c|c|c|c|c|c|c|c|}
\hline & & Disagree & & $\begin{array}{l}\text { Neither ag } \\
\text { disagree }\end{array}$ & ee nor & $\begin{array}{l}\text { Strongly } \\
\text { agree }\end{array}$ & & Agree & & \\
\hline Mean & 2.7 & Mean & 2.9 & Mean & 3.6 & Mean & 8.5 & Mean & 10.3 & \\
\hline Standard & 0.26034 & Standard & 0.48189 & Standard & 0.63595 & Standard & 1.16666 & Standard & 0.59721 & \\
\hline Error & 2 & Error & 4 & Error & 9 & Error & 7 & Error & 6 & \\
\hline Median & 2.5 & Median & 2.5 & Median & 4 & Median & 8 & Median & 10.5 & \\
\hline $\begin{array}{l}\text { Mode } \\
\text { Standard }\end{array}$ & 2 & $\begin{array}{l}\text { Mode } \\
\text { Standard }\end{array}$ & 2 & $\begin{array}{l}\text { Mode } \\
\text { Standard }\end{array}$ & 4 & $\begin{array}{l}\text { Mode } \\
\text { Standard }\end{array}$ & 12 & $\begin{array}{l}\text { Mode } \\
\text { Standard }\end{array}$ & 10 & \\
\hline Deviatio & 0.82327 & Deviatio & 1.52388 & Deviatio & & Deviatio & 3.68932 & Deviatio & 1.88856 & \\
\hline $\mathrm{n}$ & 3 & $\mathrm{n}$ & 4 & $\mathrm{n}$ & 2.01108 & $\mathrm{n}$ & 4 & $\mathrm{n}$ & 2 & \\
\hline Sample & 0.67777 & Sample & 2.32222 & Sample & 4.04444 & Sample & 13.6111 & Sample & 3.56666 & \\
\hline Variance & 8 & Variance & 2 & Variance & 4 & Variance & 1 & Variance & 7 & \\
\hline Kurtosis & -1.0435 & Kurtosis & $\begin{array}{r}0.81915 \\
3\end{array}$ & Kurtosis & $\begin{array}{r}0.30547 \\
6\end{array}$ & Kurtosis & 0.30951 & Kurtosis & 0.56861 & $\underline{521}$ \\
\hline Skewnes & 0.68698 & Skewnes & 1.14916 & Skewnes & - & Skewnes & 0.26552 & Skewnes & - & \\
\hline $\mathrm{s}$ & 2 & $\mathrm{~s}$ & 6 & $\mathrm{~s}$ & 0.02869 & $\mathrm{~S}$ & 1 & $\mathrm{~S}$ & 0.41568 & \\
\hline Range & 2 & Range & 5 & Range & 7 & Range & 12 & Range & 6 & \\
\hline $\begin{array}{l}\text { Minimu } \\
\mathrm{m}\end{array}$ & 2 & $\begin{array}{l}\text { Minimu } \\
\mathrm{m}\end{array}$ & 1 & $\begin{array}{l}\text { Minimu } \\
\mathrm{m}\end{array}$ & 0 & $\begin{array}{l}\text { Minimu } \\
\mathrm{m}\end{array}$ & 3 & $\begin{array}{l}\text { Minimu } \\
\mathrm{m}\end{array}$ & 7 & \\
\hline $\begin{array}{l}\text { Maximu } \\
\mathrm{m}\end{array}$ & 4 & $\begin{array}{l}\text { Maximu } \\
\mathrm{m}\end{array}$ & 6 & $\begin{array}{l}\text { Maximu } \\
\mathrm{m}\end{array}$ & 7 & $\begin{array}{l}\text { Maximu } \\
\mathrm{m}\end{array}$ & 15 & $\begin{array}{l}\text { Maximu } \\
\mathrm{m}\end{array}$ & 13 & \\
\hline Sum & 27 & Sum & 29 & Sum & 36 & Sum & 85 & Sum & 103 & \\
\hline Count & 10 & Count & 10 & Count & 10 & Count & 10 & Count & 10 & \\
\hline
\end{tabular}




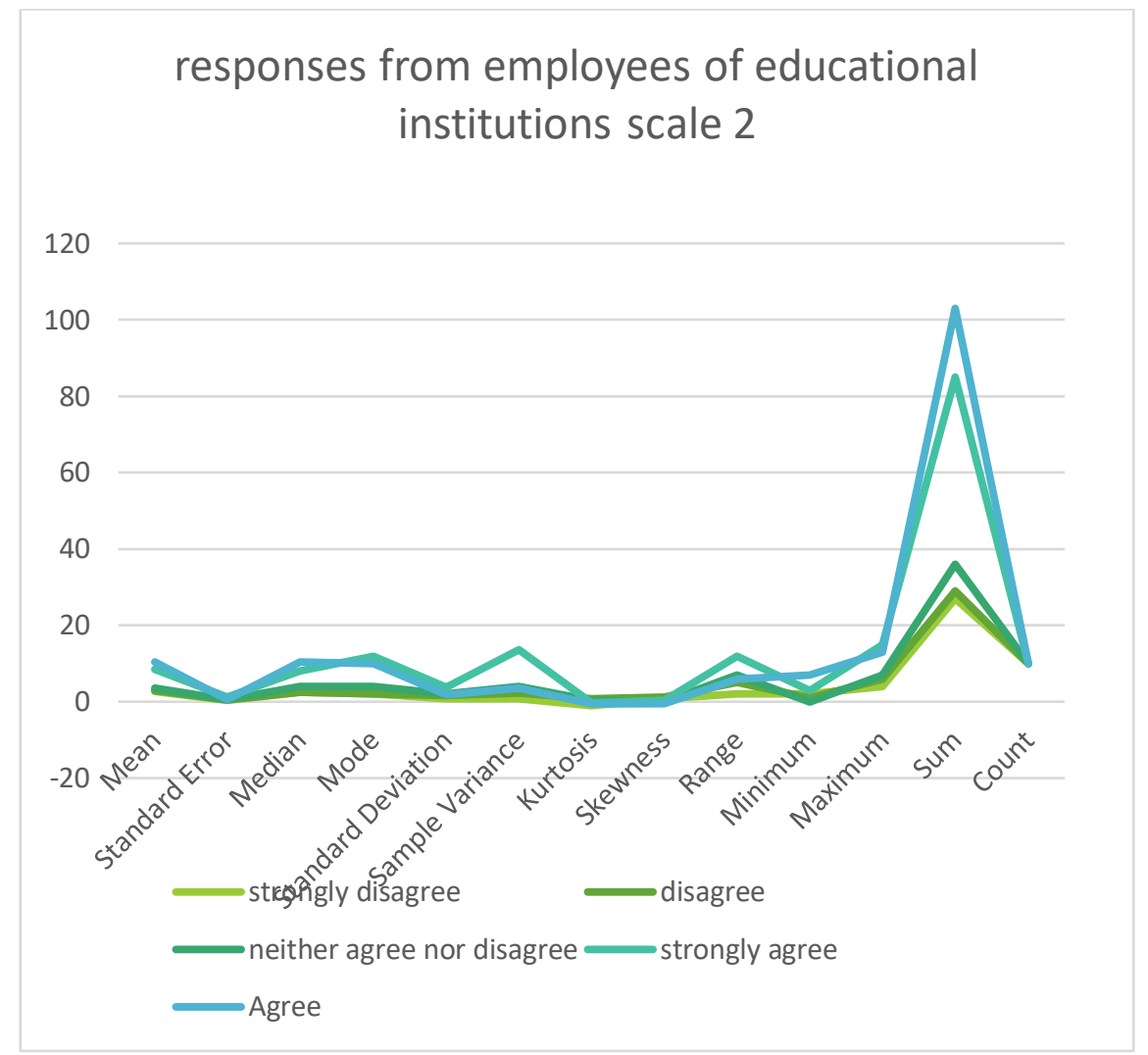

Figure 3

On scale 2 all responses have high strongly agree points and agree points.

\section{Reliability Test}

To measure the internal consistency of the construct of likert scale, the widely used measure is Cronbach's Alpha $\alpha$. This type of tests to see if multiple questions on likerrt scale survey are reliable. This test will tell if the test youhave designed is accurately measuring the variable of Psychological behaviour of workforce.

Cronbach Alpha Formula used is:

$$
\alpha=\frac{\text { N.c }}{V+(N-1) \cdot c}
$$

Where $\mathrm{N}=$ number of items

$\mathrm{C}=$ average covariance between item pairs

$$
\mathrm{V}=\text { average variance }
$$


Table 3: Table showing Cronbach Alpha scores for likert scale 1 \& 2

\begin{tabular}{|c|c|}
\hline Sectors & $\begin{array}{c}\text { Cronbach alpha } \\
\text { values }\end{array}$ \\
\hline Educational institutions & 0.930 \\
\hline IT Industry & 1.04 \\
\hline SMEs & 1.05 \\
\hline others & 0.69 \\
\hline
\end{tabular}

$\alpha \geq 0.9$ is excellent. All Cronbach alpha values are above 0.9 with all sectors thus the likert scale construct is Reliable. The Cronbach Apha value for educational institutions is 0.93 and for It industry it is 1.04 and for SMEs is 1.05 and others .69 which are more than $\alpha \geq 0.9$ thus, the construct used for the study is reliable.

\section{Findings \& Conclusions}

The respondents to the survey are fewer and even then, the opinion of the respondents is valuable to this study. The employees from educational institutions have responded in large numbers then IT and SMEs. All respondents agree to the statements based on salary, socializing and promotions and events. The descriptive statistics indicates there is close relationship between expected scores and actual scores. The model developed from the scores of the responses gives way for further studies on building organization culture common to all workforce. The factors to determine organization work culture finally are

1. Recognition at workplace

2. Gatherings with peer members

3. Performance based promotions

4. Incentives for higher performance

5. Appreciation awards and certificates

6. Organizing More socializing events

The productivity and sustainability is closely related to the attributes derived from the study. Thus, employees belonging to which ever sector expect salary in constraint to their job and recognition, socializing and rewards are commonly agreed and strongly agreed points on the scale. If the work culture changes based on gender discrimination and promotions the workforce show change in the behavior by showing disagreement in their responses. The construct of likert scale set organization cultural. The list is not exhaustive, this study gives way for further research to explore more attributes for setting organization culture.

Year 4/ 2020, Volume-4, Issue-5 | WwW.ispecjournal.org 
The reliability test using Cronbach Alpha test proves that the construct of questions and statements in likert scale is reliable based on alpha values. Thus every organization may decide culture based on the points used for obtaining responses through the construct.

\section{References}

André de Waal, 25.25HPO Center, the Netherlands, The Role of Behavioral Factors and National Cultures in Creating Effective Performance Management Systems, February 2006

Chris Joseph, The Effects of Merit-Based Promotion Vs. Seniority, . How to Make Unbiased, Merit-Based Employee Promotion Decisions With Data, Community Contributor, Aug 28, 2018.

Gail M. Sullivan, MD, MPH and Anthony R. Artino, Jr, PhD, Dec 2013. Analyzing and Interpreting Data From Likert-Type Scales

Icohere, Four Ways Associations Use Peer Groups to Recruit and Support Members December 11, 2014. JEFF HADEN, 25 Rewards That Great Employees Actually Love to ReceiveLose your Employee-of-theMonth program. Here are some rewards your staff really deserve -- and want. BY, CONTRIBUTING EDITOR, INC.@JEFF_HADEN.

Joanne Sammer, Reward Top Performers Even in Lean Times Despite tight budgets, it's important to carve out rewards for top performers. By,HR magazine, SHRM 2020.

Mary L. McHugh, .2015,Interrater reliability: the kappa statistic

"Prachi Juneja, The article is Written By and Reviewed By Management Study Guide Content Tea" .

Steven E. Phelan, Promotion Systems And Organizational Performance: A Contingency Model,

November,. Fayetteville State University, Zhiang (John) Lin, University of Texas at Dallas.

33 Rewards and Recognition Ideas to Boost Employee Recognition [2020 Updated] 28 October 2020,

The Importance of Social Events at Work

Study note "problems of changing organization culture.

Wietrak,, The Key to Creating an Employee Recognition Program that Works, March 2019. Emilia O.C. Tanner Connect on Twitter, Facebook, and LinkedIn www.octanner.com

https://www.creativebusinessinc.com/blog-index/a-guide-to-peer-advisory-groups-and-their-benefits-forbusiness-owners-and-leaders

https://opentext.wsu.edu/carriecuttler/chapter/reliability-and-validity-of-measurement/ www.researchgate.com

Year 4/ 2020, Volume-4, Issue-5 | WWW.ispecjournal.org 


\section{APPENDIX I}

Table 2: Table showing responses for scale $1 \& 2$ on 5 points from employees working in Educational Institutions

\begin{tabular}{|l|l|l|l|l|l|l|l|l|l|l|l|}
\hline $\begin{array}{l}\text { scale I } \\
\text { Questi } \\
\text { on Nos. }\end{array}$ & $\begin{array}{l}\text { strong } \\
\text { ly } \\
\text { disagr } \\
\text { ee }\end{array}$ & $\begin{array}{l}\text { disagr } \\
\text { ee }\end{array}$ & $\begin{array}{l}\text { neithe } \\
\text { r } \\
\text { agree } \\
\text { nor } \\
\text { disagr } \\
\text { ee }\end{array}$ & $\begin{array}{l}\text { strong } \\
\text { agree }\end{array}$ & $\begin{array}{l}\text { Agr } \\
\text { ee }\end{array}$ & $\begin{array}{l}\text { Scale 2 } \\
\text { questi } \\
\text { on } \\
\text { Nos. }\end{array}$ & $\begin{array}{l}\text { Strong } \\
\text { ly } \\
\text { disagr } \\
\text { ee }\end{array}$ & $\begin{array}{l}\text { disagr } \\
\text { ee }\end{array}$ & $\begin{array}{l}\text { Neithe } \\
\text { r } \\
\text { agree } \\
\text { not } \\
\text { disagr } \\
\text { ee }\end{array}$ & $\begin{array}{l}\text { strong } \\
\text { agree }\end{array}$ & $\begin{array}{l}\text { Agr } \\
\text { ee }\end{array}$ \\
\hline I1 & 3 & 3 & o & 62 & 42 & II 1 & 4 & 4 & 6 & 3 & 10 \\
\hline I2 & 2 & 2 & 2 & 12 & 10 & II 2 & 1 & 8 & 6 & 4 & 9 \\
\hline I3 & 3 & 2 & 4 & 4 & 12 & II 3 & 4 & 3 & 11 & 7 & 6 \\
\hline I4 & 3 & 3 & 7 & 7 & 11 & II 4 & 2 & 3 & 6 & 9 & 8 \\
\hline I5 & 4 & 6 & 6 & 3 & 9 & II 5 & 2 & 7 & 10 & 2 & 7 \\
\hline I6 & 2 & 3 & 3 & 8 & 12 & II 6 & 2 & 2 & 5 & 4 & 14 \\
\hline I7 & 2 & 2 & 4 & 7 & 13 & II 7 & 3 & 2 & 7 & 5 & 11 \\
\hline I8 & 2 & 2 & 4 & 9 & 11 & II 8 & 4 & 1 & 6 & 9 & 8 \\
\hline I9 & 4 & 5 & 4 & 8 & 7 & II 9 & 2 & 2 & 4 & 10 & 10 \\
\hline I10 & 2 & 1 & 2 & 15 & 8 & II 10 & 1 & 1 & 7 & 10 & 9 \\
\hline
\end{tabular}

Scale 1: All 10 questions have highest number of respondents with agree and strongly agree answers, for statement No.1, 2,3, 4, 6,7,8 which are conscious behavior with boss, recognition to ones work in team, motivation due to informal organization structure and highest no. of employees strongly agree for performance-based promotion for high productivity in an organization.

Scale 2: Highest number of respondents agree that their salary is in constraint with their expectations, and highest number of employees agree that socializing increases belongingness towards the organization, and highest number of employees agree that there should be common work culture in all organizations.

Year 4/ 2020, Volume-4, Issue-5 | WWW.ispecjournal.org 
Table 3: Table showing Reponses for scale $1 \& 2$ on 5 points from employees working in Information Technology industry

\begin{tabular}{|c|c|c|c|c|c|c|c|c|c|c|c|}
\hline $\begin{array}{l}\text { Scale } 1 \\
\text { Questi } \\
\text { on } \\
\text { Nos. }\end{array}$ & $\begin{array}{l}\text { strong } \\
\text { ly } \\
\text { disagr } \\
\text { ee }\end{array}$ & $\begin{array}{l}\text { disagr } \\
\text { ee }\end{array}$ & $\begin{array}{l}\text { neithe } \\
\mathbf{r} \\
\text { agree } \\
\text { nor } \\
\text { disagr } \\
\text { ee }\end{array}$ & $\begin{array}{l}\text { strong } \\
\text { ly } \\
\text { agree }\end{array}$ & $\begin{array}{l}\text { Agr } \\
\text { ee }\end{array}$ & $\begin{array}{l}\text { Scale } 2 \\
\text { Question } \\
\text { Nos. }\end{array}$ & $\begin{array}{l}\text { Strong } \\
\text { ly } \\
\text { disagr } \\
\text { ee }\end{array}$ & $\begin{array}{l}\text { disagr } \\
\text { ee }\end{array}$ & $\begin{array}{l}\text { Neithe } \\
\mathbf{r} \\
\text { agree } \\
\text { not } \\
\text { disagr } \\
\text { ee }\end{array}$ & $\begin{array}{l}\text { strong } \\
\text { ly } \\
\text { agree }\end{array}$ & $\begin{array}{l}\text { Agr } \\
\text { ee }\end{array}$ \\
\hline I1 & $\mathbf{0}$ & $\mathbf{0}$ & $\mathbf{0}$ & 3 & 1 & II 1 & 1 & 2 & $\mathbf{0}$ & $\overline{0}$ & 1 \\
\hline I2 & $\mathbf{0}$ & $\mathbf{0}$ & 2 & $\overline{\mathbf{0}}$ & 2 & II 2 & 1 & 1 & 1 & $\mathbf{0}$ & 1 \\
\hline I3 & 0 & 2 & 2 & 0 & 0 & II 3 & 1 & 0 & 2 & 0 & 1 \\
\hline I4 & 0 & 0 & 0 & 0 & 4 & II 4 & 0 & 2 & 1 & 0 & 1 \\
\hline I5 & 1 & $\mathbf{0}$ & 1 & 1 & 1 & II 5 & 1 & $\mathbf{0}$ & 3 & $\mathbf{0}$ & 0 \\
\hline I6 & $\mathbf{0}$ & $\mathbf{0}$ & 1 & 0 & 3 & II 6 & 1 & 1 & $\mathbf{0}$ & 1 & 1 \\
\hline I7 & $\mathbf{0}$ & $\mathbf{0}$ & 1 & $\mathbf{0}$ & 3 & II 7 & 1 & $\mathbf{0}$ & 1 & $\mathbf{0}$ & 2 \\
\hline I8 & 1 & 1 & 1 & 1 & 1 & II 8 & 0 & 0 & 1 & 1 & 2 \\
\hline 19 & 0 & 0 & 1 & 1 & 1 & II 9 & $\overline{\mathbf{0}}$ & 1 & 1 & $\mathbf{0}$ & 2 \\
\hline I10 & $\mathbf{0}$ & $\mathbf{0}$ & 2 & 1 & 1 & II 10 & 0 & 0 & 1 & 1 & 2 \\
\hline
\end{tabular}

Table 4: Table showing responses for scale $1 \& 2$ on 5 points from employees of Small and Medium Enterprises

\begin{tabular}{|c|c|c|c|c|c|c|c|c|c|c|c|}
\hline $\begin{array}{l}\text { Scale } 1 \\
\text { Questi } \\
\text { on } \\
\text { Nos. }\end{array}$ & $\begin{array}{l}\text { strong } \\
\text { ly } \\
\text { disagr } \\
\text { ee }\end{array}$ & $\begin{array}{l}\text { disagr } \\
\text { ee }\end{array}$ & $\begin{array}{l}\text { neithe } \\
\text { r } \\
\text { agree } \\
\text { nor } \\
\text { disagr } \\
\text { ee }\end{array}$ & $\begin{array}{l}\text { strong } \\
\text { ly } \\
\text { agree }\end{array}$ & $\begin{array}{l}\text { Agr } \\
\text { ee }\end{array}$ & $\begin{array}{l}\text { Scale } 2 \\
\text { Question } \\
\text { Nos. }\end{array}$ & $\begin{array}{l}\text { Strong } \\
\text { ly } \\
\text { disagr } \\
\text { ee }\end{array}$ & $\begin{array}{l}\text { disagr } \\
\text { ee }\end{array}$ & $\begin{array}{l}\text { Neithe } \\
\mathbf{r} \\
\text { agree } \\
\text { not } \\
\text { disagr } \\
\text { ee }\end{array}$ & $\begin{array}{l}\text { strong } \\
\text { ly } \\
\text { agree }\end{array}$ & $\begin{array}{l}\text { Agr } \\
\text { ee }\end{array}$ \\
\hline I1 & $\mathbf{0}$ & $\mathbf{0}$ & $\mathbf{0}$ & 1 & $\mathbf{0}$ & II 1 & $\overline{\mathbf{0}}$ & $\mathbf{0}$ & $\mathbf{0}$ & 1 & 1 \\
\hline I2 & $\mathbf{0}$ & $\mathbf{0}$ & $\mathbf{0}$ & $\mathbf{0}$ & 1 & II 2 & $\mathbf{0}$ & $\mathbf{0}$ & $\mathbf{0}$ & $\mathbf{0}$ & 1 \\
\hline I3 & $\mathbf{0}$ & $\mathbf{0}$ & $\mathbf{0}$ & 1 & $\mathbf{0}$ & II 3 & 0 & 0 & $\mathbf{0}$ & 1 & $\mathbf{0}$ \\
\hline I4 & $\mathbf{0}$ & $\mathbf{0}$ & 0 & $\overline{\mathbf{0}}$ & 1 & II 4 & $\overline{\mathbf{0}}$ & $\mathbf{0}$ & $\mathbf{0}$ & $\mathbf{0}$ & 1 \\
\hline I5 & 0 & 0 & 0 & $\mathbf{0}$ & 1 & II 5 & $\mathbf{0}$ & $\mathbf{0}$ & 0 & 0 & 1 \\
\hline I6 & O & O & O & $\mathbf{0}$ & 1 & II 6 & $\mathbf{0}$ & $\mathbf{0}$ & $\mathbf{0}$ & $\mathbf{0}$ & 1 \\
\hline
\end{tabular}

Year 4/ 2020, Volume-4, Issue-5 | WWW.ispecjournal.org 


\begin{tabular}{|l|l|l|l|l|l|l|l|l|l|l|l|}
\hline I7 & 0 & 0 & 0 & 1 & 0 & II 7 & 0 & 0 & 0 & 1 & 0 \\
\hline I8 & 0 & 0 & 0 & 0 & 1 & II 8 & 0 & 0 & 0 & 0 & 1 \\
\hline I9 & 0 & 0 & 1 & 0 & 0 & II 9 & 0 & 0 & 0 & 1 & 0 \\
\hline I10 & 0 & 0 & 0 & 0 & 1 & II 10 & 0 & 0 & 0 & 0 & 1 \\
\hline
\end{tabular}

Scale 1: mostly All employees agree on all points of this scale

Scale 2: mostly employees agree or stongly agree on all points

Table 5: Table showing responses of scale $1 \& 2$ on 5 points from employees of other sectors who responded to our survey

\begin{tabular}{|c|c|c|c|c|c|c|c|c|c|c|c|}
\hline $\begin{array}{l}\text { Scale } 1 \\
\text { Questi } \\
\text { on } \\
\text { Nos. }\end{array}$ & $\begin{array}{l}\text { strong } \\
\text { ly } \\
\text { disagr } \\
\text { ee }\end{array}$ & $\begin{array}{l}\text { disagr } \\
\text { ee }\end{array}$ & $\begin{array}{l}\text { neithe } \\
\text { r } \\
\text { agree } \\
\text { nor } \\
\text { disagr } \\
\text { ee }\end{array}$ & $\begin{array}{l}\text { strong } \\
\text { ly } \\
\text { agree }\end{array}$ & $\begin{array}{l}\text { Agr } \\
\text { ee }\end{array}$ & $\begin{array}{l}\text { Scale } 2 \\
\text { Question } \\
\text { Nos. }\end{array}$ & $\begin{array}{l}\text { Strong } \\
\text { ly } \\
\text { disagr } \\
\text { ee }\end{array}$ & $\begin{array}{l}\text { disagr } \\
\text { ee }\end{array}$ & $\begin{array}{l}\text { Neithe } \\
\mathbf{r} \\
\text { agree } \\
\text { not } \\
\text { disagr } \\
\text { ee }\end{array}$ & $\begin{array}{l}\text { strong } \\
\text { ly } \\
\text { agree }\end{array}$ & $\begin{array}{l}\text { Agr } \\
\text { ee }\end{array}$ \\
\hline I1 & $\mathbf{0}$ & $\mathbf{0}$ & 2 & 4 & 2 & II 1 & $\mathbf{0}$ & 1 & 2 & $\mathbf{0}$ & 5 \\
\hline I2 & $\mathbf{0}$ & 1 & $\mathbf{0}$ & 5 & 2 & II 2 & $\mathbf{0}$ & 1 & 2 & 2 & 2 \\
\hline I3 & 0 & 1 & 3 & 2 & 2 & II 3 & 0 & 1 & 2 & 2 & 2 \\
\hline I4 & $\mathbf{0}$ & $\mathbf{0}$ & 2 & 3 & 3 & II 4 & $\mathbf{0}$ & 1 & 2 & 1 & 3 \\
\hline I5 & $\mathbf{0}$ & 2 & 3 & $\mathbf{0}$ & 2 & II 5 & $\mathbf{0}$ & 2 & $\mathbf{0}$ & 1 & 4 \\
\hline I6 & 0 & 1 & 2 & 1 & 4 & II 6 & 0 & 0 & 1 & 2 & 4 \\
\hline I7 & 0 & 1 & 0 & 4 & 2 & II 7 & 0 & 1 & 1 & 1 & 3 \\
\hline I8 & 0 & 0 & 3 & $\mathbf{0}$ & 5 & II 8 & 1 & 1 & 1 & 1 & 3 \\
\hline I9 & O & 0 & 1 & 4 & 2 & II 9 & 0. & 0 & $\mathbf{0}$ & 1 & 3 \\
\hline I10 & 0 & 0 & 2 & 1 & 4 & II 10 & 0 & $\mathbf{0}$ & $\mathbf{0}$ & 1 & 6 \\
\hline
\end{tabular}

Year 4/ 2020, Volume-4, Issue-5 | WWW.ispecjournal.org 


\section{Appendix II}

Table 6: Table showing descriptive statistics of responses from emplpyees of educational institutions for scale 1 and 2

\begin{tabular}{|c|c|c|c|c|c|c|c|c|c|}
\hline \multicolumn{2}{|c|}{ Strongly disagree } & \multicolumn{2}{|l|}{ disagree } & \multicolumn{2}{|c|}{$\begin{array}{l}\text { neither agree nor } \\
\text { disagree }\end{array}$} & \multicolumn{2}{|c|}{ strongly agree } & \multicolumn{2}{|l|}{ Agree } \\
\hline Mean & 4.6 & Mean & 6.2 & Mean & 13 & Mean & 12.3 & Mean & 17.4 \\
\hline Standard & & Standard & & Standard & & Standard & & Standard & \\
\hline & 2.291045 & & $3.0 / 2458$ & & $0.1481 /$ & & 5.103891 & & 8.318921 \\
\hline Median & 2 & Median & 2.5 & Median & 6.5 & Median & 8 & Median & 9 \\
\hline Mode & 2 & Mode & 2 & Mode & 6 & Mode & 4 & Mode & 9 \\
\hline $\begin{array}{l}\text { Standard } \\
\text { Deviation }\end{array}$ & 7.244922 & $\begin{array}{l}\text { Standard } \\
\text { Deviation }\end{array}$ & 9.715966 & $\begin{array}{l}\text { Standard } \\
\text { Deviation }\end{array}$ & 19.44222 & $\begin{array}{l}\text { Standard } \\
\text { Deviation }\end{array}$ & 18.03731 & $\begin{array}{l}\text { Standard } \\
\text { Deviation }\end{array}$ & 26.30674 \\
\hline $\begin{array}{l}\text { Sample } \\
\text { Variance }\end{array}$ & 52.48889 & $\begin{array}{l}\text { Sample } \\
\text { Variance }\end{array}$ & 94.4 & $\begin{array}{l}\text { Sample } \\
\text { Variance }\end{array}$ & 378 & $\begin{array}{l}\text { Sample } \\
\text { Variance }\end{array}$ & 325.3444 & $\begin{array}{l}\text { Sample } \\
\text { Variance }\end{array}$ & 692.0444 \\
\hline Kurtosis & 9.422155 & Kurtosis & 8.359275 & Kurtosis & 9.669596 & Kurtosis & 9.33566 & Kurtosis & $9.801568 \underline{528}$ \\
\hline Skewness & 3.039269 & Skewness & 2.82963 & Skewness & 3.09253 & Skewness & 3.016504 & Skewness & 3.120263 \\
\hline Range & 24 & Range & 32 & Range & 64 & Range & 61 & Range & 86 \\
\hline Minimum & 1 & Minimum & 1 & Minimum & 4 & Minimum & 2 & Minimum & 6 \\
\hline Maximum & 25 & Maximum & 33 & Maximum & 68 & Maximum & 63 & Maximum & 92 \\
\hline Sum & 46 & Sum & 62 & Sum & 130 & Sum & 123 & Sum & 174 \\
\hline Count & 10 & Count & 10 & Count & 10 & Count & 10 & Count & 10 \\
\hline $\begin{array}{l}\text { Confidenc } \\
\text { e } \\
\text { Level(95. } \\
0 \%)\end{array}$ & 5.182705 & $\begin{array}{l}\text { Confidenc } \\
\text { e } \\
\text { Level(95. } \\
0 \%)\end{array}$ & 6.950384 & $\begin{array}{l}\text { Confidenc } \\
\text { e } \\
\text { Level(95. } \\
0 \%)\end{array}$ & 13.90813 & $\begin{array}{l}\text { Confidenc } \\
\text { e } \\
\text { Level(95. } \\
0 \%)\end{array}$ & 12.90311 & $\begin{array}{l}\text { Confidenc } \\
\text { e } \\
\text { Level(95. } \\
0 \%)\end{array}$ & 18.81871 \\
\hline
\end{tabular}


Table 6: Table showing descriptive statistics for scale 1 of responses from Educational Instituition Scale 2

\begin{tabular}{|c|c|c|c|c|c|c|c|c|c|c|}
\hline & & Disagree & & $\begin{array}{l}\text { Neither ag } \\
\text { disagree }\end{array}$ & ee nor & $\begin{array}{l}\text { Strongly } \\
\text { agree }\end{array}$ & & Agree & & \\
\hline Mean & 2.7 & Mean & 2.9 & Mean & 3.6 & Mean & 8.5 & Mean & 10.3 & \\
\hline Standard & 0.26034 & Standard & 0.48189 & Standard & 0.63595 & Standard & 1.16666 & Standard & 0.59721 & \\
\hline Error & 2 & Error & 4 & Error & 9 & Error & 7 & Error & 6 & \\
\hline Median & 2.5 & Median & 2.5 & Median & 4 & Median & 8 & Median & 10.5 & \\
\hline Mode & 2 & Mode & 2 & Mode & 4 & Mode & 12 & Mode & 10 & \\
\hline Standard & & Standard & & Standard & & Standard & & Standard & & \\
\hline Deviatio & 0.82327 & Deviatio & 1.52388 & Deviatio & & Deviatio & 3.68932 & Deviatio & 1.88856 & \\
\hline $\mathrm{n}$ & 3 & $\mathrm{n}$ & 4 & $\mathrm{n}$ & 2.01108 & $\mathrm{n}$ & 4 & $\mathrm{n}$ & 2 & \\
\hline Sample & 0.67777 & Sample & 2.32222 & Sample & 4.04444 & Sample & 13.6111 & Sample & 3.56666 & 529 \\
\hline Variance & 8 & Variance & 2 & Variance & 4 & Variance & 1 & Variance & 7 & $\underline{5 \angle 9}$ \\
\hline & & & 0.81915 & & 0.30547 & & - & & - & \\
\hline Kurtosis & -1.0435 & Kurtosis & 3 & Kurtosis & 6 & Kurtosis & 0.30951 & Kurtosis & 0.56861 & \\
\hline Skewnes & 0.68698 & Skewnes & 1.14916 & Skewnes & - & Skewnes & 0.26552 & Skewnes & - & \\
\hline $\mathrm{s}$ & 2 & $\mathrm{~s}$ & 6 & $\mathrm{~s}$ & 0.02869 & $\mathrm{~S}$ & 1 & $\mathrm{~s}$ & 0.41568 & \\
\hline Range & 2 & Range & 5 & Range & 7 & Range & 12 & Range & 6 & \\
\hline $\begin{array}{l}\text { Minimu } \\
\mathrm{m}\end{array}$ & 2 & $\begin{array}{l}\text { Minimu } \\
\mathrm{m}\end{array}$ & 1 & $\begin{array}{l}\text { Minimu } \\
\mathrm{m}\end{array}$ & 0 & $\begin{array}{l}\text { Minimu } \\
\mathrm{m}\end{array}$ & 3 & $\begin{array}{l}\text { Minimu } \\
\mathrm{m}\end{array}$ & 7 & \\
\hline $\begin{array}{l}\text { Maximu } \\
\mathrm{m}\end{array}$ & 4 & $\begin{array}{l}\text { Maximu } \\
\mathrm{m}\end{array}$ & 6 & $\begin{array}{l}\text { Maximu } \\
\mathrm{m}\end{array}$ & 7 & $\begin{array}{l}\text { Maximu } \\
\mathrm{m}\end{array}$ & 15 & $\begin{array}{l}\text { Maximu } \\
\mathrm{m}\end{array}$ & 13 & \\
\hline Sum & 27 & Sum & 29 & Sum & 36 & Sum & 85 & Sum & 103 & \\
\hline Count & 10 & Count & 10 & Count & 10 & Count & 10 & Count & 10 & \\
\hline
\end{tabular}




\section{ISSN 2717-7262 ISPEC Journal of Social Sciences \& Humanities}

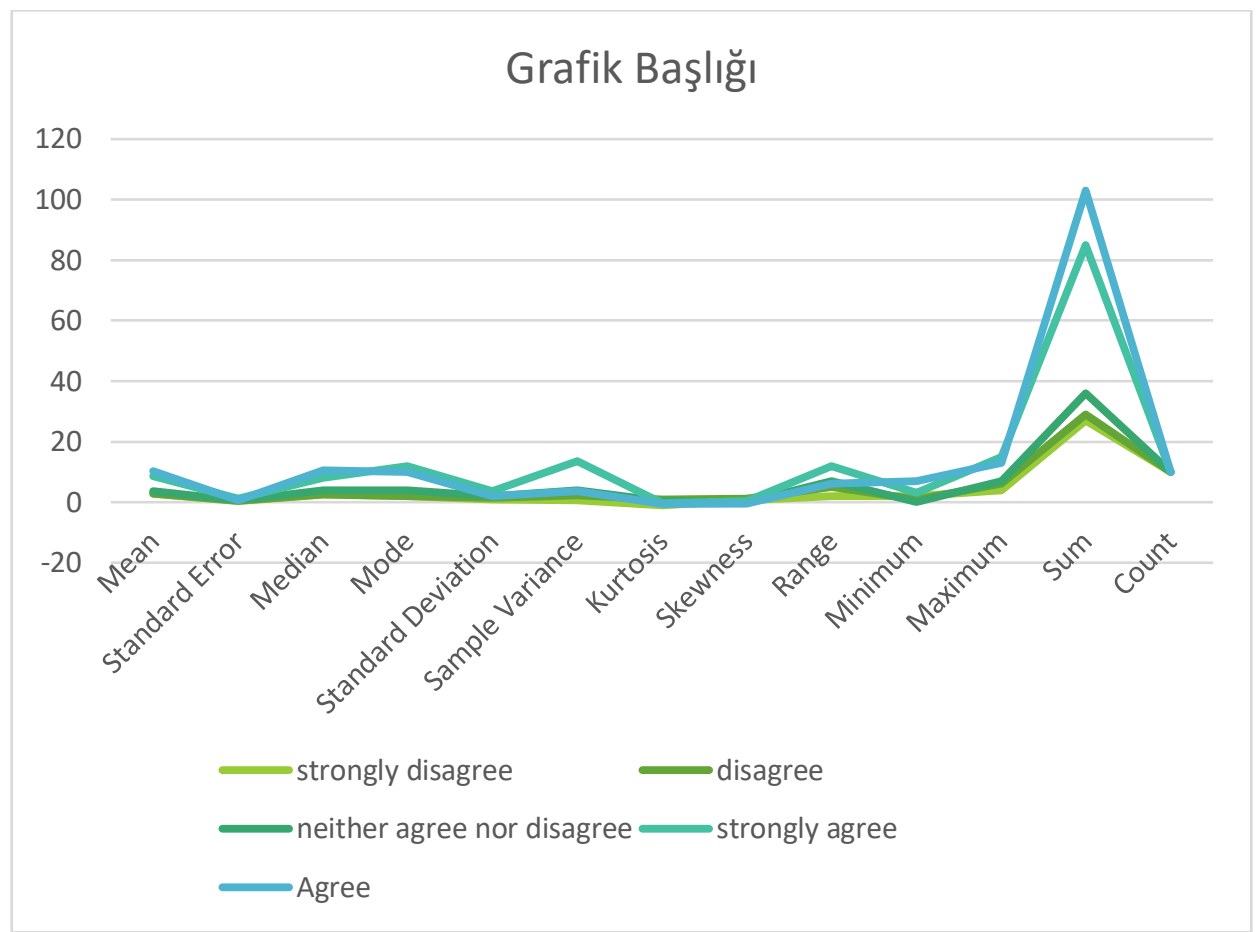

Table 7: Table showing descriptive statics for scale 1 and 2 for IT industry respondents

\begin{tabular}{|c|c|c|c|c|c|c|c|c|c|}
\hline \multicolumn{2}{|c|}{ Strongly disagree } & disagree & & \multicolumn{2}{|c|}{$\begin{array}{l}\text { neither agree nor } \\
\text { disagree }\end{array}$} & $\begin{array}{l}\text { strongly } \\
\text { agree }\end{array}$ & & Agree & \\
\hline Mean & $\begin{array}{l}0.22 \\
222 \\
2\end{array}$ & Mean & $\begin{array}{l}0.33 \\
333 \\
3\end{array}$ & Mean & $\begin{array}{l}1.22 \\
222 \\
2\end{array}$ & Mean & $\begin{array}{l}0.44 \\
444 \\
4\end{array}$ & Mean & $\begin{array}{l}1.77 \\
777 \\
8\end{array}$ \\
\hline $\begin{array}{l}\text { Standard } \\
\text { Error }\end{array}$ & $\begin{array}{l}0.14 \\
698 \\
6\end{array}$ & $\begin{array}{l}\text { Standard } \\
\text { Error }\end{array}$ & $\begin{array}{l}0.23 \\
570 \\
2\end{array}$ & $\begin{array}{l}\text { Standard } \\
\text { Error }\end{array}$ & $\begin{array}{l}0.22 \\
222 \\
2\end{array}$ & $\begin{array}{l}\text { Standard } \\
\text { Error }\end{array}$ & $\begin{array}{l}0.17 \\
568 \\
2\end{array}$ & $\begin{array}{l}\text { Standard } \\
\text { Error }\end{array}$ & $\begin{array}{l}0.43 \\
390 \\
3\end{array}$ \\
\hline Median & 0 & Median & 0 & Median & 1 & Median & 0 & Median & 1 \\
\hline Mode & 0 & Mode & 0 & Mode & 1 & Mode & 0 & Mode & 1 \\
\hline $\begin{array}{l}\text { Standard } \\
\text { Deviation }\end{array}$ & $\begin{array}{l}0.44 \\
095 \\
9 \\
\end{array}$ & $\begin{array}{l}\text { Standard } \\
\text { Deviation }\end{array}$ & $\begin{array}{l}0.70 \\
710 \\
7\end{array}$ & $\begin{array}{l}\text { Standard } \\
\text { Deviation }\end{array}$ & $\begin{array}{l}0.66 \\
666 \\
7\end{array}$ & $\begin{array}{l}\text { Standard } \\
\text { Deviation }\end{array}$ & $\begin{array}{l}0.52 \\
704 \\
6\end{array}$ & $\begin{array}{l}\text { Standard } \\
\text { Deviation }\end{array}$ & $\begin{array}{l}1.30 \\
170 \\
8 \\
\end{array}$ \\
\hline $\begin{array}{l}\text { Sample } \\
\text { Variance }\end{array}$ & $\begin{array}{l}0.19 \\
444 \\
4\end{array}$ & $\begin{array}{l}\text { Sample } \\
\text { Variance }\end{array}$ & 0.5 & $\begin{array}{l}\text { Sample } \\
\text { Variance }\end{array}$ & $\begin{array}{l}0.44 \\
444 \\
4\end{array}$ & $\begin{array}{l}\text { Sample } \\
\text { Variance }\end{array}$ & $\begin{array}{l}0.27 \\
777 \\
8\end{array}$ & $\begin{array}{l}\text { Sample } \\
\text { Variance }\end{array}$ & $\begin{array}{l}1.69 \\
444 \\
4\end{array}$ \\
\hline Kurtosis & $\begin{array}{l}0.73 \\
469 \\
4\end{array}$ & Kurtosis & 4 & Kurtosis & $\begin{array}{l}- \\
0.04 \\
018\end{array}$ & Kurtosis & $\begin{array}{l}- \\
2.57 \\
143\end{array}$ & Kurtosis & $\begin{array}{l}- \\
0.81 \\
13 \\
\end{array}$ \\
\hline Skewness & $\begin{array}{l}1.61 \\
984 \\
8\end{array}$ & Skewness & $\begin{array}{l}2.12 \\
132\end{array}$ & Skewness & $\begin{array}{l}- \\
0.25 \\
446\end{array}$ & Skewness & $\begin{array}{l}0.27 \\
105 \\
2\end{array}$ & Skewness & $\begin{array}{l}0.51 \\
994 \\
4\end{array}$ \\
\hline Range & 1 & Range & 2 & Range & 2 & Range & 1 & Range & 4 \\
\hline Minimum & 0 & Minimum & 0 & Minimum & 0 & Minimum & 0 & Minimum & 0 \\
\hline
\end{tabular}

Year 4/ 2020, Volume-4, Issue-5 | WwW.ispecjournal.org 


\section{ISSN 2717-7262 ISPEC Journal of Social Sciences \& Humanities}

\begin{tabular}{|c|c|c|c|c|c|c|c|c|c|}
\hline Maximum & 1 & Maximum & 2 & Maximum & 2 & Maximum & 1 & Maximum & 4 \\
\hline Sum & 2 & Sum & 3 & Sum & 11 & Sum & 4 & Sum & 16 \\
\hline Count & 9 & Count & 9 & Count & 9 & Count & 9 & Count & 9 \\
\hline $\begin{array}{l}\text { Confidence } \\
\text { Level(95.0\% } \\
\text { ) }\end{array}$ & $\begin{array}{l}0.33 \\
895 \\
1 \\
\end{array}$ & $\begin{array}{l}\text { Confidence } \\
\text { Level }(95.0 \% \\
\text { ) }\end{array}$ & $\begin{array}{l}0.54 \\
353\end{array}$ & $\begin{array}{l}\text { Confidence } \\
\text { Level }(95.0 \% \\
\text { ) }\end{array}$ & $\begin{array}{l}0.51 \\
244 \\
5\end{array}$ & $\begin{array}{l}\text { Confidence } \\
\text { Level }(95.0 \% \\
\text { ) }\end{array}$ & $\begin{array}{l}0.40 \\
512 \\
4 \\
\end{array}$ & $\begin{array}{l}\text { Confidence } \\
\text { Level(95.0\% } \\
\text { ) }\end{array}$ & $\begin{array}{l}1.00 \\
058 \\
2\end{array}$ \\
\hline
\end{tabular}

\begin{tabular}{|c|c|c|c|c|c|c|c|c|c|}
\hline \multicolumn{10}{|l|}{ Scale 2} \\
\hline \multicolumn{2}{|c|}{ strongly disagree } & disagree & & \multicolumn{2}{|c|}{$\begin{array}{l}\text { neither agree nor } \\
\text { disagree }\end{array}$} & \multicolumn{2}{|c|}{ strongly agree } & agree & \\
\hline Mean & $\begin{array}{l}0.5555 \\
56\end{array}$ & Mean & $\begin{array}{l}0.5555 \\
56\end{array}$ & Mean & $\begin{array}{l}1.2222 \\
22\end{array}$ & Mean & $\begin{array}{l}0.3333 \\
33\end{array}$ & Mean & $\begin{array}{l}1.3333 \\
33\end{array}$ \\
\hline $\begin{array}{l}\text { Standard } \\
\text { Error }\end{array}$ & $\begin{array}{l}0.1756 \\
82\end{array}$ & $\begin{array}{l}\text { Standard } \\
\text { Error }\end{array}$ & $\begin{array}{l}0.2421 \\
61\end{array}$ & $\begin{array}{l}\text { Standard } \\
\text { Error }\end{array}$ & $\begin{array}{l}0.2777 \\
78\end{array}$ & $\begin{array}{l}\text { Standard } \\
\text { Error }\end{array}$ & $\begin{array}{l}0.1666 \\
67\end{array}$ & $\begin{array}{l}\text { Standard } \\
\text { Error }\end{array}$ & $\begin{array}{l}0.2357 \\
02\end{array}$ \\
\hline Median & 1 & Median & 0 & Median & 1 & Median & 0 & Median & 1 \\
\hline Mode & 1 & Mode & 0 & Mode & 1 & Mode & 0 & Mode & 1 \\
\hline $\begin{array}{l}\text { Standard } \\
\text { Deviation }\end{array}$ & $\begin{array}{l}0.5270 \\
46\end{array}$ & $\begin{array}{l}\text { Standard } \\
\text { Deviation }\end{array}$ & $\begin{array}{l}0.7264 \\
83\end{array}$ & $\begin{array}{l}\text { Standard } \\
\text { Deviation }\end{array}$ & $\begin{array}{l}0.8333 \\
33\end{array}$ & $\begin{array}{l}\text { Standard } \\
\text { Deviation }\end{array}$ & 0.5 & $\begin{array}{l}\text { Standard } \\
\text { Deviation }\end{array}$ & $\begin{array}{l}0.7071 \\
07\end{array}$ \\
\hline $\begin{array}{l}\text { Sample } \\
\text { Variance }\end{array}$ & $\begin{array}{l}0.2777 \\
78\end{array}$ & $\begin{array}{l}\text { Sample } \\
\text { Variance }\end{array}$ & $\begin{array}{l}0.5277 \\
78\end{array}$ & $\begin{array}{l}\text { Sample } \\
\text { Variance }\end{array}$ & $\begin{array}{l}0.6944 \\
44\end{array}$ & $\begin{array}{l}\text { Sample } \\
\text { Variance }\end{array}$ & 0.25 & $\begin{array}{l}\text { Sample } \\
\text { Variance }\end{array}$ & 0.5 \\
\hline Kurtosis & $\begin{array}{l} \\
2.5714 \\
3 \\
\end{array}$ & Kurtosis & 0.1852 & Kurtosis & $\begin{array}{l}2.4274 \\
29\end{array}$ & Kurtosis & $\begin{array}{l}- \\
1.7142 \\
9\end{array}$ & Kurtosis & $\begin{array}{l}- \\
0.2857 \\
1\end{array}$ \\
\hline Skewness & $\begin{array}{l}- \\
0.2710 \\
5\end{array}$ & Skewness & $\begin{array}{l}1.0142 \\
59\end{array}$ & Skewness & $\begin{array}{l}1.1657 \\
14\end{array}$ & Skewness & $\begin{array}{l}0.8571 \\
43\end{array}$ & Skewness & $\begin{array}{l}- \\
0.6060 \\
9\end{array}$ \\
\hline Range & 1 & Range & 2 & Range & 3 & Range & 1 & Range & 2 \\
\hline Minimum & 0 & Minimum & 0 & Minimum & 0 & Minimum & 0 & Minimum & 0 \\
\hline Maximum & 1 & Maximum & 2 & Maximum & 3 & Maximum & 1 & Maximum & 2 \\
\hline Sum & 5 & Sum & 5 & Sum & 11 & Sum & 3 & Sum & 12 \\
\hline Count & 9 & Count & 9 & Count & 9 & Count & 9 & Count & 9 \\
\hline $\begin{array}{l}\text { Confidenc } \\
\text { e } \\
\text { Level( } 95 . \\
0 \%)\end{array}$ & $\begin{array}{l}0.4051 \\
24\end{array}$ & $\begin{array}{l}\text { Confidenc } \\
\text { e } \\
\text { Level(95. } \\
0 \%)\end{array}$ & $\begin{array}{l}0.5584 \\
24\end{array}$ & $\begin{array}{l}\text { Confidenc } \\
\text { e } \\
\text { Level(95. } \\
0 \%)\end{array}$ & $\begin{array}{l}0.6405 \\
57\end{array}$ & $\begin{array}{l}\text { Confidenc } \\
\text { e } \\
\text { Level(95. } \\
0 \%)\end{array}$ & $\begin{array}{l}0.3843 \\
34\end{array}$ & $\begin{array}{l}\text { Confidenc } \\
\text { e } \\
\text { Level(95. } \\
0 \%)\end{array}$ & $\begin{array}{l}0.5435 \\
3\end{array}$ \\
\hline
\end{tabular}


Table 8: Table showing descriptive statistics for scale $1 \& 2$ for SME repondents

\begin{tabular}{|c|c|c|c|c|c|c|c|c|c|}
\hline 0 & & 0 & & 0 & & 1 & & 0 & \\
\hline Mean & 0 & Mean & 0 & Mean & $\begin{array}{l}0.11 \\
111 \\
1\end{array}$ & Mean & $\begin{array}{l}0.22 \\
222 \\
2\end{array}$ & Mean & $\begin{array}{l}0.66 \\
666 \\
7\end{array}$ \\
\hline $\begin{array}{l}\text { Standard } \\
\text { Error }\end{array}$ & 0 & $\begin{array}{l}\text { Standard } \\
\text { Error }\end{array}$ & 0 & $\begin{array}{l}\text { Standard } \\
\text { Error }\end{array}$ & $\begin{array}{l}0.11 \\
111 \\
1\end{array}$ & $\begin{array}{l}\text { Standard } \\
\text { Error }\end{array}$ & $\begin{array}{l}0.14 \\
698 \\
6\end{array}$ & $\begin{array}{l}\text { Standard } \\
\text { Error }\end{array}$ & $\begin{array}{l}0.16 \\
666 \\
7\end{array}$ \\
\hline Median & 0 & Median & 0 & Median & 0 & Median & 0 & Median & 1 \\
\hline Mode & 0 & Mode & 0 & Mode & 0 & Mode & 0 & Mode & 1 \\
\hline $\begin{array}{l}\text { Standard } \\
\text { Deviation }\end{array}$ & 0 & $\begin{array}{l}\text { Standard } \\
\text { Deviation }\end{array}$ & 0 & $\begin{array}{l}\text { Standard } \\
\text { Deviation }\end{array}$ & $\begin{array}{l}0.33 \\
333 \\
3\end{array}$ & $\begin{array}{l}\text { Standard } \\
\text { Deviation }\end{array}$ & $\begin{array}{l}0.44 \\
095 \\
9\end{array}$ & $\begin{array}{l}\text { Standard } \\
\text { Deviation }\end{array}$ & 0.5 \\
\hline $\begin{array}{l}\text { Sample } \\
\text { Variance }\end{array}$ & 0 & $\begin{array}{l}\text { Sample } \\
\text { Variance }\end{array}$ & 0 & $\begin{array}{l}\text { Sample } \\
\text { Variance }\end{array}$ & $\begin{array}{l}0.11 \\
111 \\
1\end{array}$ & $\begin{array}{l}\text { Sample } \\
\text { Variance }\end{array}$ & $\begin{array}{l}0.19 \\
444 \\
4\end{array}$ & $\begin{array}{l}\text { Sample } \\
\text { Variance }\end{array}$ & 0.25 \\
\hline Kurtosis & $\begin{array}{l}\text { \#DI } \\
\text { V/O! }\end{array}$ & Kurtosis & $\begin{array}{l}\text { \#DI } \\
\text { V/0! }\end{array}$ & Kurtosis & 9 & Kurtosis & $\begin{array}{l}0.73 \\
469 \\
4\end{array}$ & Kurtosis & $\begin{array}{l}- \\
1.71 \\
429\end{array}$ \\
\hline Skewness & $\begin{array}{l}\text { \#DI } \\
\text { V/O! }\end{array}$ & Skewness & $\begin{array}{l}\text { \#DI } \\
\text { V/0! }\end{array}$ & Skewness & 3 & Skewness & $\begin{array}{l}1.61 \\
984 \\
8\end{array}$ & Skewness & $\begin{array}{l}- \\
0.85 \\
714\end{array}$ \\
\hline Range & 0 & Range & 0 & Range & 1 & Range & 1 & Range & 1 \\
\hline Minimum & 0 & Minimum & 0 & Minimum & 0 & Minimum & 0 & Minimum & 0 \\
\hline Maximum & 0 & Maximum & 0 & Maximum & 1 & Maximum & 1 & Maximum & 1 \\
\hline Sum & 0 & Sum & 0 & Sum & 1 & Sum & 2 & Sum & 6 \\
\hline Count & 9 & Count & 9 & Count & 9 & Count & 9 & Count & 9 \\
\hline $\begin{array}{l}\text { Confidence } \\
\text { Level( } 95.0 \% \\
\text { ) }\end{array}$ & 0 & $\begin{array}{l}\text { Confidence } \\
\text { Level(95.0\% } \\
\text { ) }\end{array}$ & 0 & $\begin{array}{l}\text { Confidence } \\
\text { Level }(95.0 \% \\
\text { ) }\end{array}$ & $\begin{array}{l}0.25 \\
622 \\
3 \\
\end{array}$ & $\begin{array}{l}\text { Confidence } \\
\text { Level(95.0\% } \\
\text { ) }\end{array}$ & $\begin{array}{l}0.33 \\
895 \\
1\end{array}$ & $\begin{array}{l}\text { Confidence } \\
\text { Level( } 95.0 \% \\
\text { ) }\end{array}$ & $\begin{array}{l}0.38 \\
433 \\
4\end{array}$ \\
\hline
\end{tabular}

\begin{tabular}{|l|l|l|l|l|l|l|l|l|l|}
\hline 0 & & 0 & & 0 & & 1 & & 1 & \\
\hline Mean & 0 & Mean & 0 & Mean & 0 & Mean & $\begin{array}{l}0.33 \\
333 \\
3\end{array}$ & Mean & $\begin{array}{l}0.66 \\
666 \\
7\end{array}$ \\
\hline $\begin{array}{l}\text { Standard } \\
\text { Error }\end{array}$ & 0 & $\begin{array}{l}\text { Standard } \\
\text { Error }\end{array}$ & 0 & $\begin{array}{l}\text { Standard } \\
\text { Error }\end{array}$ & 0 & $\begin{array}{l}\text { Standard } \\
\text { Error }\end{array}$ & $\begin{array}{l}0.16 \\
666 \\
7\end{array}$ & $\begin{array}{l}\text { Standard } \\
\text { Error }\end{array}$ & $\begin{array}{l}0.16 \\
666 \\
7\end{array}$ \\
\hline Median & 0 & Median & 0 & Median & 0 & Median & 0 & Median & 1 \\
\hline Mode & 0 & Mode & 0 & Mode & 0 & Mode & 0 & Mode & 1 \\
\hline $\begin{array}{l}\text { Standard } \\
\text { Deviation }\end{array}$ & 0 & $\begin{array}{l}\text { Standard } \\
\text { Deviation }\end{array}$ & 0 & $\begin{array}{l}\text { Standard } \\
\text { Deviation }\end{array}$ & 0 & $\begin{array}{l}\text { Standard } \\
\text { Deviation }\end{array}$ & 0.5 & $\begin{array}{l}\text { Standard } \\
\text { Deviation }\end{array}$ & 0.5 \\
\hline $\begin{array}{l}\text { Sample } \\
\text { Variance }\end{array}$ & 0 & $\begin{array}{l}\text { Sample } \\
\text { Variance }\end{array}$ & 0 & $\begin{array}{l}\text { Sample } \\
\text { Variance }\end{array}$ & 0 & $\begin{array}{l}\text { Sample } \\
\text { Variance }\end{array}$ & 0.25 & $\begin{array}{l}\text { Sample } \\
\text { Variance }\end{array}$ & 0.25 \\
\hline
\end{tabular}

Year 4/ 2020, Volume-4, Issue-5 | WWW.ispecjournal.org 


\section{ISSN 2717-7262 ISPEC Journal of Social Sciences \& Humanities}

\begin{tabular}{|c|c|c|c|c|c|c|c|c|c|}
\hline Kurtosis & $\begin{array}{l}\text { \#DI } \\
\text { V/O! }\end{array}$ & Kurtosis & $\begin{array}{l}\text { \#DI } \\
\text { V/O! }\end{array}$ & Kurtosis & $\begin{array}{l}\text { \#DI } \\
\text { V/0! }\end{array}$ & Kurtosis & $\begin{array}{l}- \\
1.71 \\
429\end{array}$ & Kurtosis & $\begin{array}{l}- \\
1.71 \\
429 \\
\end{array}$ \\
\hline Skewness & $\begin{array}{l}\text { \#DI } \\
\text { V/O! }\end{array}$ & Skewness & $\begin{array}{l}\text { \#DI } \\
\text { V/0! }\end{array}$ & Skewness & $\begin{array}{l}\text { \#DI } \\
\text { V/0! }\end{array}$ & Skewness & $\begin{array}{l}0.85 \\
714 \\
3 \\
\end{array}$ & Skewness & $\begin{array}{l}- \\
0.85 \\
714 \\
\end{array}$ \\
\hline Range & 0 & Range & 0 & Range & 0 & Range & 1 & Range & 1 \\
\hline Minimum & 0 & Minimum & 0 & Minimum & 0 & Minimum & 0 & Minimum & 0 \\
\hline Maximum & 0 & Maximum & 0 & Maximum & 0 & Maximum & 1 & Maximum & 1 \\
\hline Sum & 0 & Sum & 0 & Sum & 0 & Sum & 3 & Sum & 6 \\
\hline Count & 9 & Count & 9 & Count & 9 & Count & 9 & Count & 9 \\
\hline $\begin{array}{l}\text { Confidence } \\
\text { Level }(95.0 \% \\
)\end{array}$ & 0 & $\begin{array}{l}\text { Confidence } \\
\text { Level(95.0\% } \\
\text { ) }\end{array}$ & 0 & $\begin{array}{l}\text { Confidence } \\
\text { Level }(95.0 \% \\
\text { ) }\end{array}$ & 0 & $\begin{array}{l}\text { Confidence } \\
\text { Level }(95.0 \% \\
\text { ) }\end{array}$ & $\begin{array}{l}0.38 \\
433 \\
4\end{array}$ & $\begin{array}{l}\text { Confidence } \\
\text { Level }(95.0 \% \\
)\end{array}$ & $\begin{array}{l}0.38 \\
433 \\
4 \\
\end{array}$ \\
\hline
\end{tabular}

Table 9 Table showing descriptive statistics for scale 1 and 2 for Other sectors

\begin{tabular}{|c|c|c|c|c|c|c|c|c|c|}
\hline $\mathrm{SG}$ & & Dis & & NAND & & SA & & A & \\
\hline Mean & 0 & Mean & $\begin{array}{l}0.66 \\
666 \\
7\end{array}$ & Mean & $\begin{array}{l}1.77 \\
777 \\
8\end{array}$ & Mean & $\begin{array}{l}2.22 \\
222 \\
2\end{array}$ & Mean & $\begin{array}{l}2.88 \\
888 \\
9 \\
\end{array}$ \\
\hline $\begin{array}{l}\text { Standard } \\
\text { Error }\end{array}$ & 0 & $\begin{array}{l}\text { Standard } \\
\text { Error }\end{array}$ & $\begin{array}{l}0.23 \\
570 \\
2 \\
\end{array}$ & $\begin{array}{l}\text { Standard } \\
\text { Error }\end{array}$ & $\begin{array}{l}0.40 \\
061 \\
7\end{array}$ & $\begin{array}{l}\text { Standard } \\
\text { Error }\end{array}$ & $\begin{array}{l}0.61 \\
864\end{array}$ & $\begin{array}{l}\text { Standard } \\
\text { Error }\end{array}$ & $\begin{array}{l}0.38 \\
888 \\
9 \\
\end{array}$ \\
\hline Median & 0 & Median & 1 & Median & 2 & Median & 2 & Median & 2 \\
\hline Mode & 0 & Mode & 1 & Mode & 3 & Mode & 0 & Mode & 2 \\
\hline $\begin{array}{l}\text { Standard } \\
\text { Deviation }\end{array}$ & 0 & $\begin{array}{l}\text { Standard } \\
\text { Deviation }\end{array}$ & $\begin{array}{l}0.70 \\
710 \\
7\end{array}$ & $\begin{array}{l}\text { Standard } \\
\text { Deviation }\end{array}$ & $\begin{array}{l}1.20 \\
185\end{array}$ & $\begin{array}{l}\text { Standard } \\
\text { Deviation }\end{array}$ & $\begin{array}{l}1.85 \\
592 \\
1\end{array}$ & $\begin{array}{l}\text { Standard } \\
\text { Deviation }\end{array}$ & $\begin{array}{l}1.16 \\
666 \\
7\end{array}$ \\
\hline $\begin{array}{l}\text { Sample } \\
\text { Variance }\end{array}$ & 0 & $\begin{array}{l}\text { Sample } \\
\text { Variance }\end{array}$ & 0.5 & $\begin{array}{l}\text { Sample } \\
\text { Variance }\end{array}$ & $\begin{array}{l}1.44 \\
444 \\
4\end{array}$ & $\begin{array}{l}\text { Sample } \\
\text { Variance }\end{array}$ & $\begin{array}{l}3.44 \\
444 \\
4\end{array}$ & $\begin{array}{l}\text { Sample } \\
\text { Variance }\end{array}$ & $\begin{array}{l}1.36 \\
111 \\
1\end{array}$ \\
\hline Kurtosis & $\begin{array}{l}\text { \#DI } \\
\text { V/0 } \\
!\end{array}$ & Kurtosis & $\begin{array}{l}- \\
0.28 \\
571 \\
\end{array}$ & Kurtosis & $\begin{array}{l}- \\
1.09 \\
932 \\
\end{array}$ & Kurtosis & $\begin{array}{l}- \\
1.56 \\
6 \\
\end{array}$ & Kurtosis & $\begin{array}{l}- \\
0.80 \\
752 \\
\end{array}$ \\
\hline Skewness & $\begin{array}{l}\text { \#DI } \\
\text { V/0 } \\
!\end{array}$ & Skewness & $\begin{array}{l}0.60 \\
609 \\
2 \\
\end{array}$ & Skewness & $\begin{array}{l}- \\
0.57 \\
375 \\
\end{array}$ & Skewness & $\begin{array}{l}0.18 \\
933\end{array}$ & Skewness & $\begin{array}{l}0.87 \\
463 \\
6\end{array}$ \\
\hline Range & 0 & Range & 2 & Range & 3 & Range & 5 & Range & 3 \\
\hline Minimum & 0 & Minimum & 0 & Minimum & 0 & Minimum & 0 & Minimum & 2 \\
\hline Maximum & 0 & Maximum & 2 & Maximum & 3 & Maximum & 5 & Maximum & 5 \\
\hline Sum & 0 & Sum & 6 & Sum & 16 & Sum & 20 & Sum & 26 \\
\hline Count & 9 & Count & 9 & Count & 9 & Count & 9 & Count & 9 \\
\hline
\end{tabular}




\section{ISSN 2717-7262 ISPEC Journal of Social Sciences \& Humanities}

\begin{tabular}{|c|c|c|c|c|c|c|c|c|c|}
\hline $\begin{array}{l}\text { Confidence } \\
\text { Level( } 95.0 \\
\%)\end{array}$ & 0 & $\begin{array}{l}\text { Confidence } \\
\text { Level(95.0 } \\
\%)\end{array}$ & $\begin{array}{l}0.54 \\
353\end{array}$ & $\begin{array}{l}\text { Confidence } \\
\text { Level(95.0 } \\
\%)\end{array}$ & $\begin{array}{l}0.92 \\
382 \\
4\end{array}$ & $\begin{array}{l}\text { Confidence } \\
\text { Level }(95.0 \\
\%)\end{array}$ & $\begin{array}{l}1.42 \\
658 \\
8\end{array}$ & $\begin{array}{l}\text { Confidence } \\
\text { Level }(95.0 \\
\%)\end{array}$ & $\begin{array}{l}0.89 \\
677 \\
9\end{array}$ \\
\hline
\end{tabular}

\begin{tabular}{|c|c|c|c|c|c|c|c|c|c|}
\hline SD & & Dis & & NAND & & SA & & A & \\
\hline Mean & $\begin{array}{l}0.11 \\
111 \\
1\end{array}$ & Mean & $\begin{array}{l}0.77 \\
777 \\
8\end{array}$ & Mean & 1 & Mean & $\begin{array}{l}1.33 \\
333 \\
3\end{array}$ & Mean & $\begin{array}{l}3.33 \\
333 \\
3\end{array}$ \\
\hline $\begin{array}{l}\text { Standard } \\
\text { Error }\end{array}$ & $\begin{array}{l}0.11 \\
111 \\
1\end{array}$ & $\begin{array}{l}\text { Standard } \\
\text { Error }\end{array}$ & $\begin{array}{l}0.22 \\
222 \\
2\end{array}$ & $\begin{array}{l}\text { Standard } \\
\text { Error }\end{array}$ & $\begin{array}{l}0.28 \\
867 \\
5\end{array}$ & $\begin{array}{l}\text { Standard } \\
\text { Error }\end{array}$ & $\begin{array}{l}0.16 \\
666 \\
7\end{array}$ & $\begin{array}{l}\text { Standard } \\
\text { Error }\end{array}$ & $\begin{array}{l}0.40 \\
824 \\
8\end{array}$ \\
\hline Median & 0 & Median & 1 & Median & 1 & Median & 1 & Median & 3 \\
\hline Mode & 0 & Mode & 1 & Mode & 2 & Mode & 1 & Mode & 3 \\
\hline $\begin{array}{l}\text { Standard } \\
\text { Deviation }\end{array}$ & $\begin{array}{l}0.33 \\
333 \\
3\end{array}$ & $\begin{array}{l}\text { Standard } \\
\text { Deviation }\end{array}$ & $\begin{array}{l}0.66 \\
666 \\
7\end{array}$ & $\begin{array}{l}\text { Standard } \\
\text { Deviation }\end{array}$ & $\begin{array}{l}0.86 \\
602 \\
5\end{array}$ & $\begin{array}{l}\text { Standard } \\
\text { Deviation }\end{array}$ & 0.5 & $\begin{array}{l}\text { Standard } \\
\text { Deviation }\end{array}$ & $\begin{array}{l}1.22 \\
474 \\
5\end{array}$ \\
\hline $\begin{array}{l}\text { Sample } \\
\text { Variance }\end{array}$ & $\begin{array}{l}0.11 \\
111 \\
1\end{array}$ & $\begin{array}{l}\text { Sample } \\
\text { Variance }\end{array}$ & $\begin{array}{l}0.44 \\
444 \\
4\end{array}$ & $\begin{array}{l}\text { Sample } \\
\text { Variance }\end{array}$ & 0.75 & $\begin{array}{l}\text { Sample } \\
\text { Variance }\end{array}$ & 0.25 & $\begin{array}{l}\text { Sample } \\
\text { Variance }\end{array}$ & 1.5 \\
\hline Kurtosis & 9 & Kurtosis & $\begin{array}{l}- \\
0.04 \\
018\end{array}$ & Kurtosis & $\begin{array}{l}- \\
1.71 \\
429\end{array}$ & Kurtosis & $\begin{array}{l} \\
1.71 \\
429\end{array}$ & Kurtosis & $\begin{array}{l}2.25 \\
396 \\
8\end{array}$ \\
\hline Skewness & 3 & Skewness & $\begin{array}{l}0.25 \\
446 \\
4\end{array}$ & Skewness & $\begin{array}{l}7.14 \\
\text { E-17 }\end{array}$ & Skewness & $\begin{array}{l}0.85 \\
714 \\
3\end{array}$ & Skewness & $\begin{array}{l}1.28 \\
306 \\
6\end{array}$ \\
\hline Range & 1 & Range & 2 & Range & 2 & Range & 1 & Range & 4 \\
\hline Minimum & 0 & Minimum & 0 & Minimum & 0 & Minimum & 1 & Minimum & 2 \\
\hline Maximum & 1 & Maximum & 2 & Maximum & 2 & Maximum & 2 & Maximum & 6 \\
\hline Sum & 1 & Sum & 7 & Sum & 9 & Sum & 12 & Sum & 30 \\
\hline Count & 9 & Count & 9 & Count & 9 & Count & 9 & Count & 9 \\
\hline $\begin{array}{l}\text { Confidence } \\
\text { Level }(95.0 \% \\
)\end{array}$ & $\begin{array}{l}0.25 \\
622 \\
3 \\
\end{array}$ & $\begin{array}{l}\text { Confidence } \\
\text { Level(95.0\% } \\
\text { ) }\end{array}$ & $\begin{array}{l}0.51 \\
244 \\
5\end{array}$ & $\begin{array}{l}\text { Confidence } \\
\text { Level(95.0\% } \\
\text { ) }\end{array}$ & $\begin{array}{l}0.66 \\
568 \\
6 \\
\end{array}$ & $\begin{array}{l}\text { Confidence } \\
\text { Level(95.0\% } \\
\text { ) }\end{array}$ & $\begin{array}{l}0.38 \\
433 \\
4 \\
\end{array}$ & $\begin{array}{l}\text { Confidence } \\
\text { Level(95.0\% } \\
\text { ) }\end{array}$ & $\begin{array}{l}0.94 \\
142 \\
2\end{array}$ \\
\hline
\end{tabular}

